This is a self-archived - parallel published version of this article in the publication archive of the University of Vaasa. It might differ from the original.

\title{
Business-friendly contracting : how simplification and visualization can help bring it to practice
}

Author(s): Haapio, Helena; Barton, Thomas D.

Title: Business-friendly contracting : how simplification and visualization can help bring it to practice

Year: $\quad 2017$

Version: Accepted manuscript

Copyright C)2017 Springer International Publishing.

Please cite the original version:

Haapio, H., \& Barton, T. D., (2018). Business-friendly contracting : how simplification and visualization can help bring it to practice. In: Jacob, K., Schindler, D., Strathausen, R. (eds), Liquid Legal. Management for Professionals (pp. 371-396). Springer, Cham. https://doi.org/10.1007/978-3-319-458687_24 


\title{
Business-Friendly Contracting: How Simplification and Visualization Can Help Bring It to Practice By Helena Haapio* and Thomas D. Barton**
}

\begin{abstract}
One thesis of this book is that the legal function within businesses will shift from a paradigm of security to one of opportunity. This chapter embraces that likelihood in the context of business contracting, where voices calling for a major shift are starting to surface. It explores how contracts can be used to reach better outcomes and relationships, not just safer ones. It introduces the concept of business-friendly contracting, highlighting the need for contracts to be seen as business tools rather than exclusively as legal tools, and working as business enablers rather than obstacles. By changing the design of contracts and the ways in which those contracts are communicated - through simplification and visualization, for example-legal and business operations can be better integrated. Contracts can then be more useful to business, and contract provisions can actually become more secure by becoming easier to negotiate and implement.
\end{abstract}

Keywords. Contract design, design thinking, collaboration, communication, functionality, information design, proactive contracting, proactive/preventive law (PPL), simplification, visualization

\footnotetext{
${ }^{*}$ Assistant Professor of Business Law, University of Vaasa; International Contract Counsel, Lexpert Ltd.

** Louis and Hermione Brown Professor of Law, California Western School of Law. The Authors are grateful to Leila Hamhoum for her editorial assistance. Copyright 2016. The Authors.
} 


\section{Introduction}

In the hands of the lawyers who traditionally draft contracting documents, the primary goal for contracts is that they be "legal-friendly:" legal formalities should be observed by invoking specialized vocabulary, and legal risks should be allocated clearly between opposing parties. Each lawyer typically seeks to limit liability for his or her client, and to shift business as well as legal risks to the other side.

This Chapter describes and urges a different vision: to make contracting "businessfriendly." Business-friendly contracting must ensure that the agreement can be legally enforced; but it should do so using language that is comprehensible to everyone involved in forming and implementing the exchange. Furthermore, business-friendly contracting stresses the value-enhancing possibilities of contracting relationships that are collaborative rather than adversarial. Transitioning from legal-friendly to business-friendly contracting can be achieved by practicing long-standing methods of Preventive and Proactive Law ("PPL"), as well as fast-emerging principles of Contract Design. By changing the design as well as the mentality of contracting, legal and business operations can be more strongly linked; hidden value may be revealed; and contracts can become more secure even as those new opportunities are explored.

Part 2 below introduces the evolution of traditional contracting into businessfriendly contracting by describing the work of the International Association for Contract and Commercial Management (IACCM). IACCM (2015a) summarizes "10 Pitfalls" which characterize traditional contracting (See also Hughes 2015). Part 3 then describes how these pitfalls can be transformed into business-friendly contracting through PPL and the emerging tools of Contract Design: simplification, visualization, and collaboration. Part 4 offers examples of using these techniques in corporate practice and in related research. Working 
together, business and legal can co-create business-friendly documents of many sorts: certainly contracts, but also proposals, disclosures, bylaws, policies, and "How We Work" guides. The PPL/Business-Friendly ideas and methods further the joint ends of opportunity and security through stronger clarity, participation, understanding of underlying strategic significance, and collaboration.

\section{Traditional Contracting versus Business-Friendly Contracting}

The chart below depicts the "10 Pitfalls" that IACCM identifies as snaring practitioners into traditional contracting practices. Collectively, the pitfalls reflect what IACCM annual surveys of its members prove: that negotiators all over the world spend much of their time preparing for failure rather than securing success and opportunity. ${ }^{1}$ (See IACCM 2014a, 2015b; Bergman 2015) Year after year, limitation of liability and indemnification clauses have retained their top positions in the most negotiated contract terms. Yet instead of providing the desired security and certainty, this focus may actually lead to lost opportunity, value erosion, and conflict. Time and money are being spent on lengthy negotiations over legal issues, when the focus should be on business issues and how the parties can succeed together-goals that this chapter hopes to further. Here below is IACCM's description of the 10 Pitfalls (Figure 1):

\footnotetext{
${ }^{1}$ The most recent Top Negotiated Terms 2015 survey was undertaken by IACCM during May-August 2015, with replies representing more than 10,000 negotiators based in over 100 countries. The respondents reflect primarily large organizations, mostly doing business internationally. (IACCM 2015b, pp. 6, 9).
} 


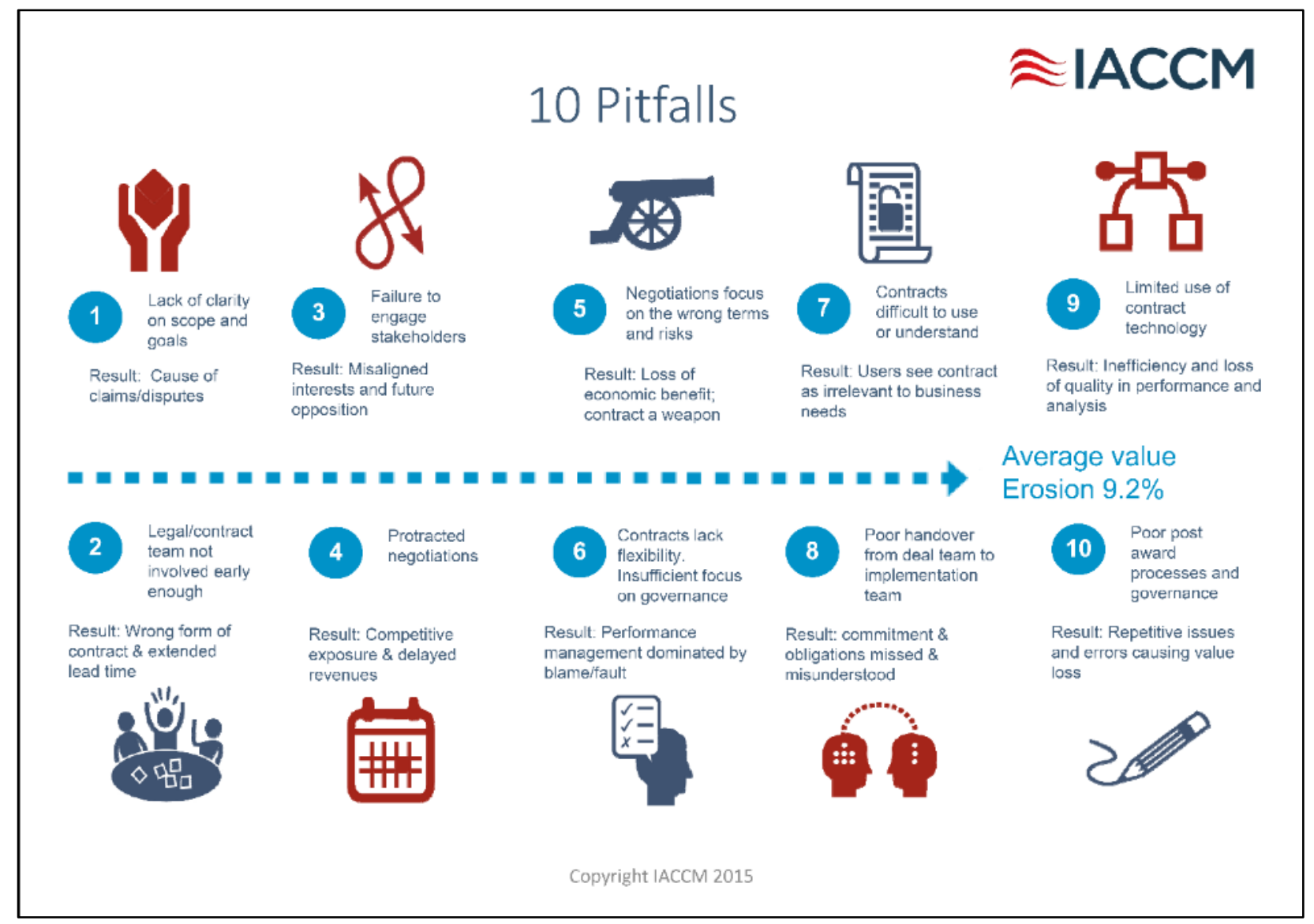

Figure 1: 10 Pitfalls (Cummins 2015). Copyright IACCM 2015. Used with permission.

Noting that the pitfalls lead to average value erosion of over $9 \%,{ }^{2}$ IACCM seeks the transformation of each pitfall into a positive "Attribute" of successful contracting. Below is IACCM's depiction of the completed transformation of Pitfalls to Attributes (Figure 2):

\footnotetext{
2 This statistic, and others in IACCM 2015a, is drawn from IACCM research with its global, cross-industry membership, representing more than 12,000 organizations. See IACCM 2015a, p. 4.
} 


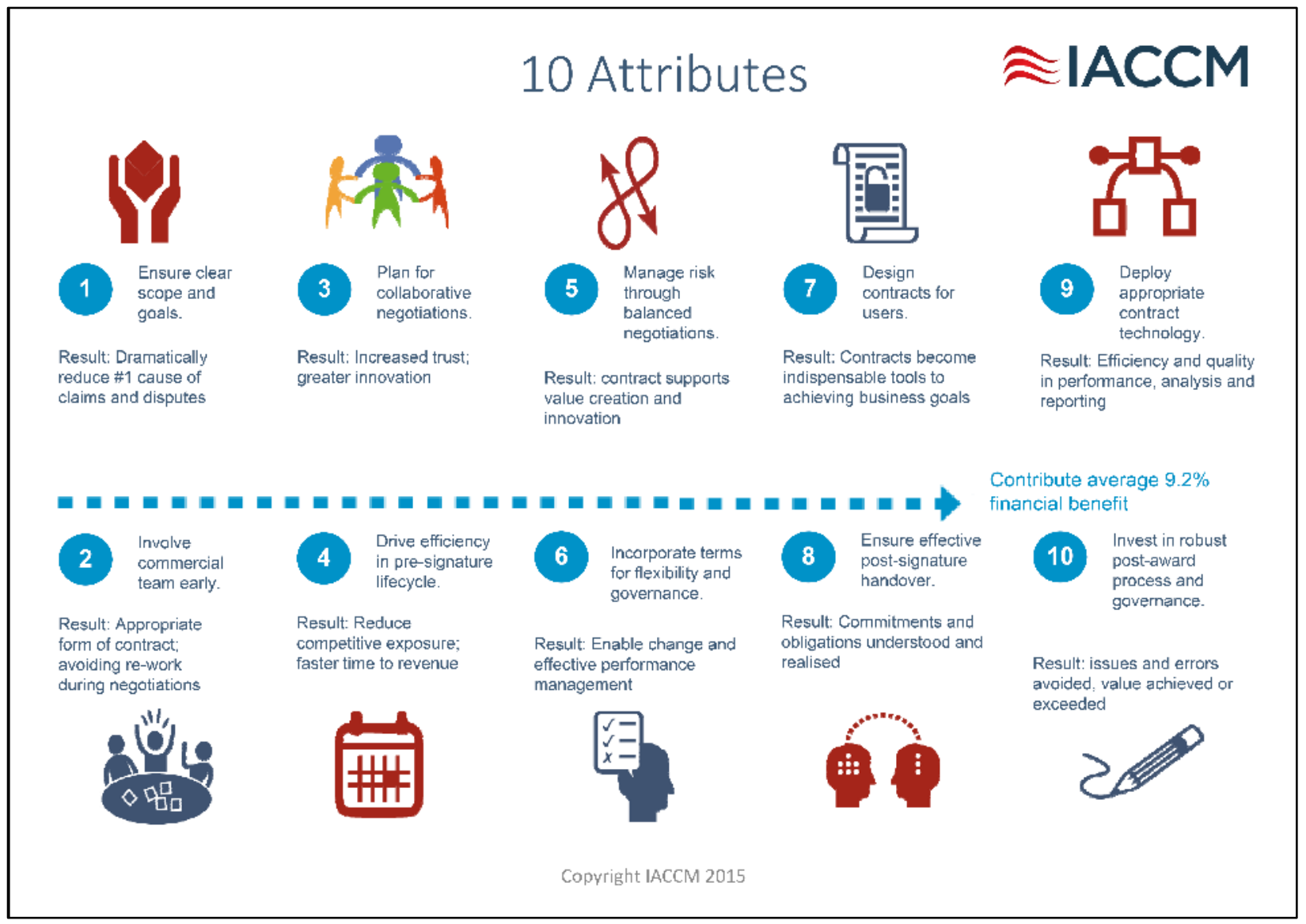

Figure 2: Pitfalls to Attributes (Cummins 2015). Copyright IACCM 2015. Used with permission.

This Chapter fully shares the goal of transforming contract Pitfalls to contract Attributes. But how can that be accomplished? We explore in Part 2.2 below how PPL methods and mentality can help to achieve this evolution from traditional to what we term business-friendly contracting. First, however, we will identify common themes among the Pitfalls, describing the dysfunctional cycle that can come to characterize traditional contracting.

\subsection{The Need for Simplified Language and Fewer Self-Protective Clauses}

We first enter the traditional contracting cycle through a combination of Pitfall \#7, that "contracts [are] difficult to use or understand," resulting in "users see[ing] contracts as 
irrelevant to business needs;" and Pitfall \#5, that "negotiations focus on the wrong terms and risks," resulting in "loss of economic benefit" and turning contracts into "a weapon." Pitfall \#7 (difficult to use) and Pitfall \#5 (too aggressive and adversarial) stem from the same root causes: an exaggerated concern among lawyers for the security of the transaction, and a failure to imagine that transactional security can actually be more strongly enhanced by using different methods than burdening the document with overly-elaborated legal language focusing on failure, disputes, and remedies.

Lawyers and business managers alike should realize the destructive impacts of jargon-laden, self-protective contract language. Such language can: (1) impair implementation of the contract; and (2) lead eventually to missed value and opportunities in the economic exchange itself (Cummins 2015). The way in which concern for security is addressed, in other words, ends up undermining opportunity. This opposition between security and opportunity, however, is not inherent or necessary. It can be transcended through simplification, visualization, and better-integrated communication between business and legal - as well as among all parts of a business and its contractual partners.

\subsubsection{Impaired Functionality; Challenges in Contract Implementation}

The business functionality of contracts can be impaired when their drafters use language that pays too much attention to legal functionality. Difficult language and selfprotective content go hand in hand in this privileging of legal needs over business needs. When lawyers draft contracts, they often focus too strongly on imagined courtroom settings, rather than the far more immediate business settings. Their attention is too often directed on whether their language would prevail in court if its meaning were disputed by other lawyers. So lawyers tend to write contract terms for other legal professionals, not for 
the delivery teams and project managers who need documents they can easily work with and act upon. As a consequence, the contract implementers may create their own "translations" of those contracts, widening the gap between what the contract says (what Stewart Macaulay calls the "paper deal") and what the original business planners and negotiators mean for the exchange (the "real deal") (Macaulay 2003).

That disjuncture of language between the paper deal and the real deal can lead to confusion and possible contract breaches. Worse, it may legalize the resolution of problems that otherwise might have been dealt with through business flexibility and compromise. Because the paper deal elaborates legal language and concepts, Pitfall \#6 is commonplace: contracts' "lack of flexibility" with an "insufficient focus on governance." As a result, "performance management [becomes] dominated by blame/fault" that characterizes legal outcomes. Once a problem arises, if business practice does not accord with the legal interpretation of the contract document, then the contract has the potential of being turned into a courtroom weapon by one party or the other. To guard against such courtroom losses, however, both sides "weaponize" the contract even further through Pitfall \#5: they insert the self-protective substantive provisions of disclaimers, indemnities, and liquidated damages.

\subsubsection{Missed Value and Opportunities}

The exaggerated focus on legal needs at the expense of business needs is reflected in Pitfall \#4: "protracted negotiations" leading to the dangers of "competitive exposure and delayed revenues." Those lengthy negotiations and missed opportunities again often stem from the difficult language that is routinely used in contracts. The language can needlessly isolate lawyers and business negotiators from one another, because business negotiators 
cannot readily participate fully in creating the legal agreements that should be memorializing the discussions among contracting parties. ${ }^{3}$ Pitfall \#1 is the ironic result: a "lack of clarity on scope and goals," causing claims and disputes. The contract is both overwritten (with self-protective clauses) and underwritten (lacking sufficient attention to the core terms of the actual economic exchange). At least in part, the complexity of contract language drives a wedge between legal and business functions, which is reflected in Pitfalls $\# 2$ and \#3: the legal/contract team is not involved early enough, and vital stakeholders are not sufficiently engaged.

Engaging stakeholders and broadening the use of contracts is difficult, however, so long as contracts are burdened by language that is largely decipherable only by legal and contracts experts. Poor communication and integration at the front end then may be repeated both at implementation and when business conditions require a change in the contract terms. Adding to the challenges is the limited use of contract technology, Pitfall \#9, resulting in "inefficiency and loss of quality in performance and analysis". The consequences include Pitfall \#8, "poor handover from deal team to implementation team," resulting in "commitment and obligations missed and misunderstood;" and Pitfall \#10, "poor postaward processes and governance," leading to "repetitive issues and errors causing value loss."

\subsection{Transitioning to Business-Friendly Contracting}

The end-result of the traditional contracting cycle-repetitive errors and losses and considerable value erosion-serves well to introduce the ideas of PPL. PPL is comprised of

\footnotetext{
${ }^{3}$ According to Deepak Malhotra, in the process, many key decisions have been left to the lawyers, even in areas where business managers and subject matter experts could (and should) have made an important contribution; the latter, according to Malhotra, are in a much stronger position to negotiate better outcomes and relationships, not just safer ones. See Malhotra 2012, pp. 363-364. Emphasis added.
} 
two main components, namely "Preventive Law" and "Proactive Law." Preventive Law focuses on dysfunctional cycles that generate recurring losses. It seeks to identify and understand the conflicting elements of a system, as we have done above, that, unless somehow resolved, will continue to generate problems. ${ }^{4}$ Proactive Law adds a focus to achieving positive goals and value. ${ }^{5}$ Together, PPL can alter mentalities and harness tools toward smoother operations and successful outcomes.

\subsubsection{Preventive Law}

Traditionally, the focus in the legal field has been on the past, mainly on failures and how to react to them through legal proceedings, remedies to force compliance, sanctions, punishment, fines, and so on. Preventive Law promotes a different approach: one where the focus is on the future and on using the law and legal skills to prevent disputes and eliminate causes of problems (Barton 2007). In doing so, Preventive Law has similarities with preventive medicine, a branch of medical science dealing with methods of preventing the occurrence of disease - here, the "disease" of legal trouble, disputes, and litigation. Preventive Law thus emphasizes the lawyer's role as a planner, advisor, or problem solver. In the words of Edward A. Dauer (1988): "Litigation law is mostly law. Preventive law is mostly facts. And the critical time for preventive lawyering is when those facts are first being born. As a lawyer speaking to business people, I would have one request of them: Please let us be involved in the making of those facts."

The following table (Table 1) illustrates the shift of mindset and focus that the proponents of Preventive Law have proposed since the 1950s.

\footnotetext{
${ }^{4}$ For a general overview and elaboration of preventive and problem solving methods, see Barton 2009.

${ }^{5}$ For the background of Preventive Law and Proactive Law, see Haapio 2008, 2013a and 2013b and BergerWalliser \& Østergaard 2012.
} 
Table 1. Preventive Law: Shifting Focus from the Past to the Future (Haapio 2013b, p. 39)

\begin{tabular}{|l|l|}
\hline \multicolumn{1}{|c|}{ Focus away from } & \multicolumn{1}{c|}{ Focus toward } \\
\hline - the past & - the future \\
- minimizing cost & - eliminating causes \\
- winning in court & - preventing litigation \\
- lawyers as fighters & - lawyers as advisors, planners and \\
& problem-solvers \\
\hline
\end{tabular}

\subsubsection{Proactive Law and Proactive Contracting}

With the development of what is now known as the Proactive Law approach, a new dimension was added to Preventive Law. In addition to minimizing problems and risk, the proactive approach focuses on enabling success and enhancing opportunities. Using the medical analogy, in the proactive approach the focus is not just on preventing problems or "legal ill-health". The goal is to promote "legal well-being": embedding legal knowledge and skills in corporate culture, strategy and everyday actions to actively promote success, ensure desired outcomes, balance risk with reward, and prevent problems. (Haapio 2013b, p. 39) The approaches specifically called Proactive Contracting and Proactive Law emerged in the Nordic countries, initiated by a small team of Finnish researchers and practitioners (one of this Chapter's authors being among them) in the late 1990s and early 2000s. ${ }^{6}$ In the

\footnotetext{
${ }^{6}$ The first publication mentioning the proactive approach was "Quality Improvement through Proactive Contracting" by Helena Haapio in 1998. Since then, a growing body of literature, conferences, and books has contributed to the further development of the approach. The early experiments led to the formation of the Nordic School of Proactive Law, http://www.proactivelaw.org and of the Proactive ThinkTank, www.proactivethinktank.com. The mission of the ThinkTank is to provide a forum for business leaders, lawyers, academics and other professionals to discuss, develop and promote the proactive management of relationships, contracts and risks and the prevention of legal uncertainties and disputes. (See ProActive ThinkTank mission statement 2007). The Nordic School's and ProActive ThinkTank's conferences have led to the publication of several books, including Wahlgren 2006, Nystén-Haarala 2008, Haapio 2008, and BergerWalliser \& Østergaard 2012. Collaboration between participants in the Nordic School, the ProActive ThinkTank, and legal scholars in the United States has enriched the proactive approach and expanded its reach. These undertakings have explored the use of the law for competitive advantage and the interaction between law and
} 
context of contracting, the pioneers of the approach merged quality and risk management principles with Preventive Law, thereby adding the promotive dimension to the preventive dimension. This laid the conceptual foundation for a new way of thinking: "proactivity = prevention plus"7. The goal of Proactive Contracting, according to Soile Pohjonen (2002, p. v), is that the contracting parties achieve the goal of their collaboration in accordance with their will. This requires, Pohjonen continues, above all, a careful investigation of their goal and will, and the skill to create a clear and legally robust framework for their implementation.

The following table (Table 2) illustrates the shift of mindset and focus that the proponents of Proactive Law have proposed:

Table 2. Proactive Law: Shifting Focus from Prevention to Promotion (Haapio 2013b, p. 41)

\begin{tabular}{|c|c|}
\hline Focus not just on & Focus also on \\
\hline $\begin{array}{l}\text { - } \text { rules, legal tools: helping the } \\
\text { parties to comply with the rules } \\
\text { - minimizing risks, problems, } \\
\text { disputes, losses } \\
\text { - preventing causes of failure and } \\
\text { negative effects } \\
\text { - lawyers as advisors, practicing } \\
\text { preventive law; the law office as a } \\
\text { preventive law laboratory (See } \\
\text { Brown 1956) }\end{array}$ & $\begin{array}{l}\text { - goals, managerial tools: enabling } \\
\text { the parties to reach their objectives } \\
\text { - maximizing opportunities, desired } \\
\text { outcomes, benefits } \\
\text { - promoting drivers of success and } \\
\text { positive effects } \\
\text { - lawyers as designers and coaches, } \\
\text { working with clients as part of } \\
\text { cross-professional teams (See } \\
\text { Haapio 2006, p. } 30 \text { ) }\end{array}$ \\
\hline
\end{tabular}

Proactive Law literature has addressed extensively the reasons and objectives of its call for a paradigm shift; less addressed is how to make it happen (Berger-Walliser 2012, p.

strategy; see, e.g. Siedel \& Haapio 2010, Siedel \& Haapio 2011, and DiMatteo, Siedel \& Haapio 2012. For the history of the Proactive Law movement, see also Berger-Walliser 2012, with references.

${ }^{7}$ Also used in the form "proactive = preventive plus promotive". 
31). ${ }^{8}$ This chapter represents a step toward effecting the paradigm shift: turning Proactive Law into practice.

The promotive dimension of the proactive approach has a positive and constructive emphasis. It involves using contracts to enable the parties to reach their business objectives. In order to do so, contracts must be usable and well suited for their purposes. For business, the contract itself is not the goal: its successful implementation is the goal (See Haapio 2013b; Ertel 2004, p. 62). ${ }^{9}$

\subsubsection{Moving Away from Traditional Contracting}

The diagnosis of the Pitfalls of traditional contracting identifies an ongoing dynamic of personnel who fail to communicate early enough, and with enough shared vocabulary, to align contracting documents well enough with the real aims of the parties. The elements of the traditional contracting system speak different languages, and focus on different goals. Such diversity of function is not necessarily bad: division of labor is efficiency-enhancing so long as the various parts of the system can communicate well with one another. But that does not happen fully in traditional contracting. The language used in contracts artificially raises information costs. The vocabulary is so specialized, and the text is so packed with legal concepts rather than business language, that the contract cannot effectively speak to many people on the business side who are in charge of planning, pricing, negotiating, or

\footnotetext{
${ }^{8}$ What is needed, according to Berger-Walliser (2012), are case studies, identification of best practices, and more distinctive methods and tools to turn Proactive Law into practice. According to Thomas D. Barton (2008, pp. 41-42), when contracts lawyers envision a potential problem, they tend to revert to the dominant legal paradigm in their analysis: "the lawyerly imagination looks backward rather than forward, in order to prevail in the courtroom [...] they rearrange the present contract language so as to be able to win that legal contest. [...] What is needed instead is a mentality toward preempting the problem from arising - reducing the client's risk even while being proactive toward achieving the client's goals." See also DiMatteo, Siedel \& Haapio 2012, p. 106.

${ }^{9}$ Similarly, EESC 2009, p. 32 (§ 6.11): "The life cycle of a piece of legislation does not begin with the drafting of a proposal or end when it has been formally adopted. A piece of legislation is not the goal; its successful implementation is."
} 
implementing the agreement or passing its terms on to sub-contractors. According to IACCM research, more than 9 out of 10 managers admit that they find contracts difficult to read or understand (IACCM 2015a, p. 6). Furthermore, the felt need to produce traditional legal language in contracts diverts drafters' attention away from the needed integration among those who construct the business transaction, and those who must carry it out.

The proactive suggestions for remedying this dysfunction are several. In this chapter, we focus on three of them: simplification of contract language and design; visualization; and collaborative contracting. Each of these methods reduces the barriers to effective communications within an organization, and between contracting parties. They make concepts and ideas more accessible, and they prompt stronger cooperation and flexibility.

Part 3 will summarize each of these three methods; together, they are important parts of a broader PPL-inspired move toward business-friendly contracting. Part 4 will offer examples where business-friendly approaches have been implemented.

\section{Business-Friendly Tools: Simplification, Visualization, and Collaboration}

If your company's current contracts are complex, you are not alone. Many top managers recognize a growing problem that contracting processes and documents are complex - too complex for companies' own personnel as well as customers and suppliers to handle. This is especially true for small and medium sized enterprises (SMEs). ${ }^{10}$ On the sellside, the consequence can be fewer winning bids, lost sales, and value erosion during implementation. On the buy-side, if the bidding process or documents seem too complicated or time consuming, there will be no SME bidders. Further, if the bidders do not

\footnotetext{
${ }^{10}$ Recent research in both private and public procurement confirms that for many SMEs, contracts are overly legalistic and difficult to work with. See, e.g., Patajoki 2013; Haapio 2013 a.
} 
understand the contracts they enter into, misunderstanding easily leads to a breakdown in relationships, and poor or late delivery. According to surveys conducted by the IACCM, major areas of weaknesses include:

- disagreements over contract scope;

- performance failures due to over-commitment or disagreement over what was committed; and

- inappropriate contract structures (See IACCM 2014a, 2015b; Bergman 2015).

As surveyed below, the tools of simplification, visualization, and collaboration can begin to address these weaknesses by clarifying terms, and by improving communication among contract negotiators, drafters, and implementers.

\subsection{Simplification}

Most of us have probably been told that our contracts are not simple; they are too long, too complex, and hard to work with. If we want to prevent misunderstanding, disagreements, and other pitfalls, what can we do to simplify our contracts? ${ }^{11}$

To begin with, we can start to see ourselves and contracts differently: ourselves as designers and contracts as business tools. Contracts contain vital business information, not just legal provisions. They are also about roles, responsibilities, and requirements that need to be translated into action and procedures and timelines that need to be followed. When we see the role of contracts as communication tools, it becomes obvious that contracts need to be designed, not just drafted.

\footnotetext{
${ }^{11}$ Simple, for the purposes of this chapter, means not complex or complicated. By simplification we mean making contracts less complex or complicated - they may still not become simple.
} 
In our previous work, we have looked into what business lawyers can learn from design thinking (Haapio 2013a; Berger-Walliser, Barton \& Haapio (forthcoming)) in general and information designers (Haapio \& Passera 2013) ${ }^{12}$ in particular. In the following, we will look into some tools and methods that we can borrow from the designers' toolbox.

In any (re)design project, the designer takes the user's situation as the point of departure. Irrespective of what one seeks to simplify, the effort needs to start with the users. A simple contract is one that is considered simple by its intended users. Different users have different backgrounds, skills, competencies, needs, and expectations. Contracts offer themselves as a particularly interesting field of simplification, because of their two quite different audiences: business users and legal users. Traditionally, the focus of contract crafters has been on the needs and expectations of the legal users, such as courts and arbitrators who may be asked to interpret the contract in case of a dispute. In this chapter, our focus is not primarily on such users; it is on those users who are not lawyers or contracts professionals. For them, any contract, even one that may seem simple and familiar to an expert, may be too complex and intimidating. And let's admit it: most contracts today are not simple even for the experts.

A systematic approach to contract simplification can be based on three key building blocks developed by Alan Siegel and Irene Etzkorn (2013) in their book Simple: 1) empathy with the users' needs and expectations; 2) clarity through the use of both plain language and design; and 3) distillation of the communication, boiling it down to its essence. These three key requirements are illustrated in Figure 3:

\footnotetext{
12 See generally the movement toward using design methods and tools in legal context, e.g., Margaret Hagan, http://www.margarethagan.com (Accessed March 30, 2016) and Szabo 2010.
} 


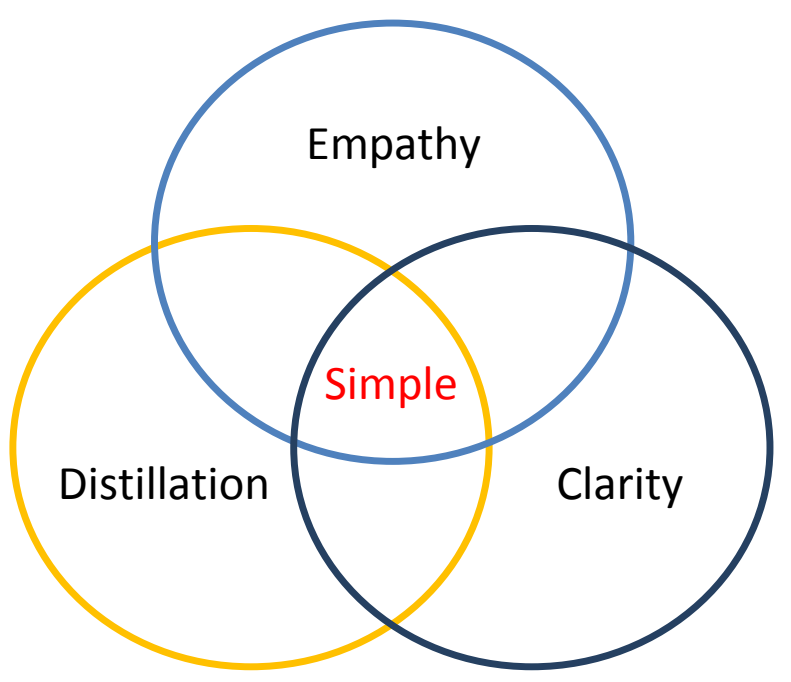

Figure 3: The Three Building Blocks of Simplicity

(The idea of the image is adapted from Siegel \& Etzkorn 2013, p. 49)

To simplify business users' experience of contracts, two approaches predominate:

either hiding complexity by providing a better "user interface;" or changing contracts themselves to make them less complex. Information design scholarship divides the available methods into two categories: optimization, which includes plain language and clear typography that improve but may not fundamentally change a given document; and transformation, which includes a range of more radical strategies such as distillation, abstraction, layering and visualization (Waller 2011c).

Layering is a particularly useful method for contracts, as it allows adaptation to multiple user needs. As the term suggests, layering creates alternative strata of information that vary in depth or style: in the context of contracts, one layer might include the text of the contract as is; another the headings or keywords of each clause; and a layer between these two might show in laymen's terms what the clause means. Layering responds not only to differing needs of different users, but also to the needs of one user at different times, when either careful study may be needed, or just a quick reminder of some general points. 
It also can express information in different formats - for example icons or images versus words (For practical examples, see e.g., Waller 2015, pp. 13-16).

Creative Commons (http://creativecommons.org) is perhaps the best-known example: their copyright licenses incorporate a three-layer design seeking to ensure that both the creators of works and their users can understand their rights. ${ }^{13}$ Clicking on the icons reveals a plain-language version of the license terms: the icons inform users about the possibilities and limitations of, for instance, sharing or remixing the licensed content. ${ }^{14}$ If additional information is required, the full text is also available just one click away. There is the so-called Legal Code (the "lawyer readable" version, the full license), the Commons Deed (the "human readable" version), and the "machine readable" version of the license, with the Commons Deed acting "as a user-friendly interface to the Legal Code beneath" (See Creative Commons 2015).

\subsection{Visualization}

"Visualization" builds on the goals and methods of simplification, by employing visual images to supplement textual language. Graphs, charts, timelines, diagrams, flowcharts, decision-trees-all of these and more can depict information in easily digested formats (Barton, Berger-Walliser \& Haapio 2013; See also Passera, Haapio \& Barton 2013; Passera \& Haapio 2013a, 2013b; Haapio \& Passera 2013). "Such techniques could be used directly in a contract, as part of the drafting process. Or visualization can be about a contract, a separate document that assists all those who are involved in the planning, review, or approval of a

\footnotetext{
${ }^{13}$ For an image of the three layers of Creative Commons licenses ("Legal Code," "Human Readable," and “Machine Readable," see Creative Commons 2015.

${ }^{14}$ For an icon summarizing the dimensions and choices of licenses, see http://wisesearch.weebly.com/uploads/1/1/3/6/11361394/1762233_orig.gif (Accessed March 30, 2016).
} 
contract or in monitoring or implementing its terms." (Barton, Berger-Walliser \& Haapio 2013, p. 48)

The aims of visualization have been summarized as follows:

1) Clarifying what written language does not manage to fully explain;

2) Making the logic and structure of the documents more visible;

3) Giving both overview and insight into complex terms and processes;

4) Supporting evidence, analysis, explanation, and reasoning in complex settings;

5) Providing an alternative access structure to the contents, especially to the non-experts working with the document;

6) Helping the parties articulate tacit assumptions and clarify and align expectations; and

7) Engaging stakeholders who have been alienated by the conventional look and feel of contracts. (Passera, Haapio \& Barton 2013)

Like the tools available in simplification, one need not be professionally trained in design to make helpful use of visualization methods. Even simple charts or diagrams can further the goals of more easily understood documents, and prompt better communication. For more complex relationships, working with a professional information designer can be especially helpful.

Depicted below is one example of such a successful collaboration (Barton, Haapio \& Borisova 2015). Figure 4 illustrates the gradual transfer of ownership - together with 
particular business and legal risks, rights, and duties-over a 15 year contractual

relationship between a supplier and purchaser of equipment (This figure first appeared in Passera, Haapio \& Barton 2013, p. 43). The multiple timeline shows the schedule of behaviors and events, starting with periodic payments from the buyer and extending beyond the lapse of the warranty, plotted against their shifting responsibilities. The information is displayed in a format that is easy to follow, encouraging ongoing use of the contract to monitor implementation over the years.

Transfer of ownership, risks, costs and responsibilities

Belongs to the the Purchase

Belongs to the Supplier

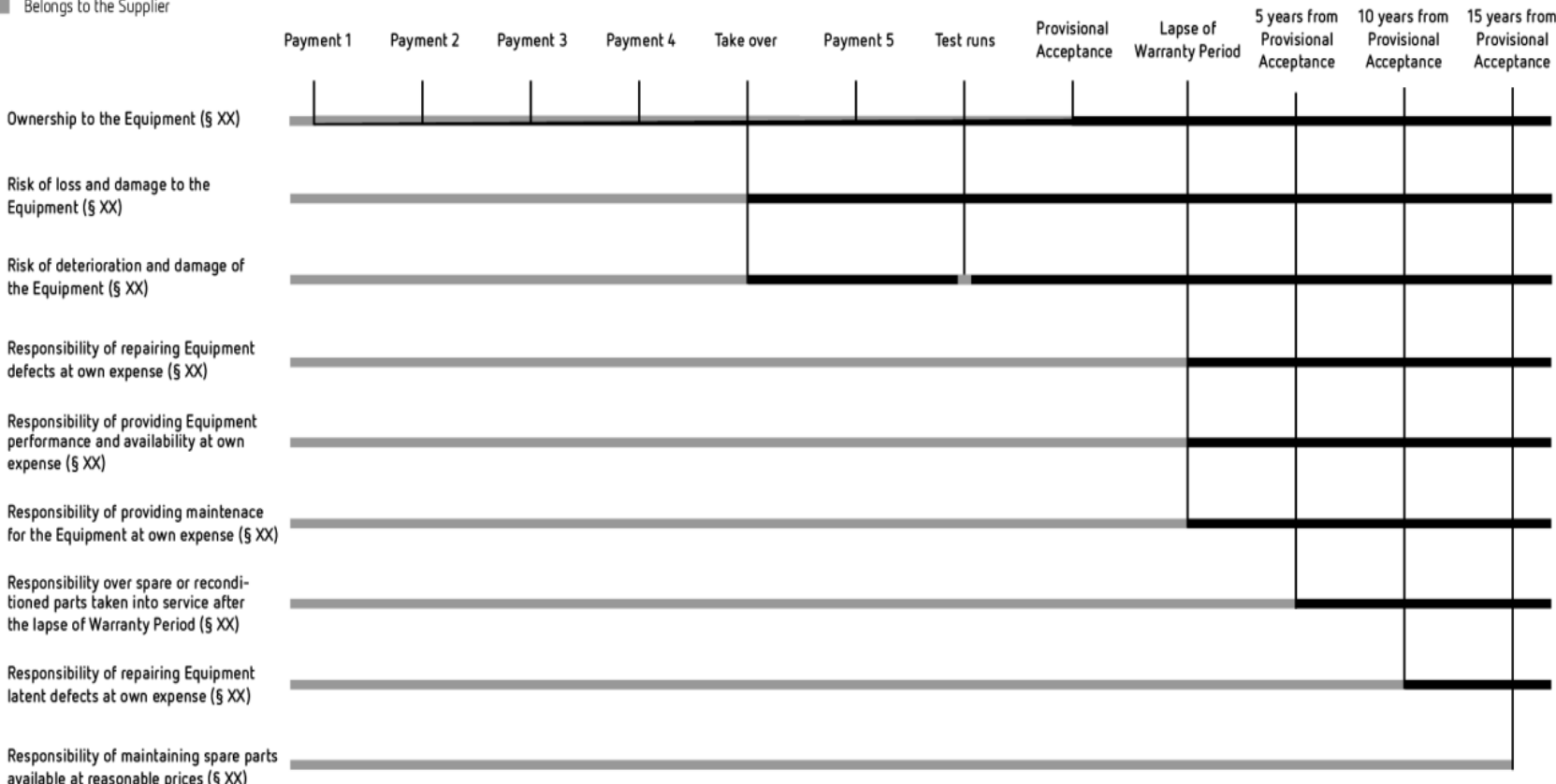
available at reasonable prices $(\S X X)$

Figure 4. Multiple Timelines Showing Transfer of Ownership and the Allocation of Risk, Cost, and Responsibilities between Parties (@ 2012. Aalto University. Image by Stefania Passera. Used with permission.)

\subsection{Collaboration}

"Collaboration" in contracting is the simple idea that parties to a contract are better off thinking of themselves and working as partners, rather than as adversaries (Mosten 
2009. See also Barton 2012, 2016). Collaboration is directly linked with the methods and goals of PPL: "better relationships, better communication, and contextual understandings that will prevent problems and facilitate success" (Barton 2012).

Collaboration explicitly recognizes that contracting embraces personal relationships, as well as legal and economic ties. As depicted below in Figure 5, contracting should be thought of as three overlapping spheres that work together:

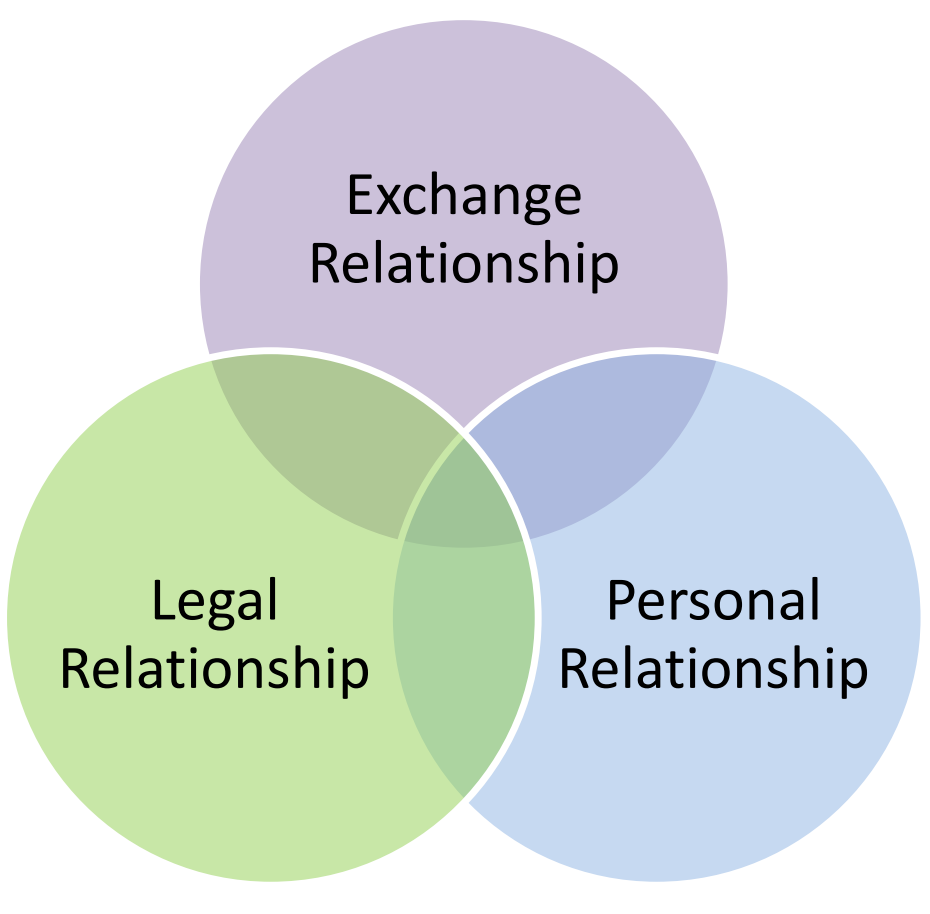

Figure 5: The Three Relationships of Contracting ${ }^{15}$

As suggested above in this chapter, various barriers can drive apart the "legal" and "business" spheres. Perhaps in part because of that lack of integration, neither lawyers nor business managers typically acknowledge fully the human relationships that importantly accompany the negotiation and implementation of a deal (Barton 2012). Collaborative contracting consciously reflects on those ties, and attempts to reunite the legal, economic, and personal relational spheres toward mutual benefit.

\footnotetext{
15 This diagram also appears in Barton, Haapio \& Borisova 2015, p. 17.
} 
Should collaborative intentions and expected practices be part of the actual contract documents? The advantages of doing so were emphasized by Jacqui Crawford of RollsRoyce: the parties disclose from the outset their respective interests, their baseline expectations, and a process for addressing and managing the changes that will inevitably occur over the life of a long term contract (Cummins \& Crawford 2010). Revealing underlying interests advances both the economic exchange perspective and the relational perspective. It also promotes finding win-win solutions where problems emerge.

In drafting the document, the parties can express both the general intentions they have worked out during the planning/negotiation stage, and also include as much detail as possible about the process that they have devised for periodic communication. Statements of their relational expectations should go beyond labels, but also be openended to set up basic norm expectations. (Barton 2012)

These norm expectations could include any or all of the following: to share more information about underlying interests; to work toward sharing risks in a balanced way, so as to satisfy both sides of those party interests; to hold periodic meetings following contract formation, so as to monitor performance quality; and to be open to one another's needs for flexibility in meeting commitments (Barton 2012). Matthew Jennejohn (2008) has researched specific examples of collaboration, extracted from contracts between parties like Cisco \& KMPG, Coca-Cola \& Synomyx, and Intel \& Phoenix Technologies. These companies adopted communication enhancing measures like interacting teams, exchange of on-site personnel, and creation of a joint research steering committee. To measure the success of 
these efforts, they included general benchmarking clauses with specific metrics. Finally, they established helpful feedback loops to improve long-term performance. Would such collaborative terms be warranted in every contract? Not necessarily: importantly, collaborative terms can be used selectively. Some of the provisions above are more demanding of time, money, and organizational coordination than others (Barton 2012).

As we have written before, successful collaboration is more than just good intentions. It involves a mentality and skills that may be relatively unfamiliar or even uncomfortable. For lawyers, it means that they address more than the language in contracting documents:

Healthy economic and personal relationships need not rely solely on legal rights. Where lawyers work toward making the economic and personal relationships stronger, therefore, the burden of dealing with risks does not fall exclusively on airtight legal language in the contract. Lawyers should therefore embrace the value of non-legal communication. That in turn requires that the lawyers learn much more about the economic exchanges that are the subject of the contracts. They should treat their clients more like partners who are capable of contributing significantly to the success of the lawyer's efforts. (Barton, Haapio \& Borisova 2015, p. 19)

As to managers, "collaboration requires first that they not abdicate too much responsibility for formal contract processes to their lawyers" (Barton, Haapio \& Borisova 2015, p. 19). Furthermore: 
Managers should also understand the worlds of their employees and any subcontractors. Managers should flatten hierarchies that, for example, prevent production or sales personnel from making suggestions about the terms of prospective contracts or the implementation of existing contracts. Finally, managers should invest time in talking with contractual counterparts about contract goals, risks, and implementation. In many cases managers should not be reluctant to share information about the economic or strategic interests that prompt willingness to enter into a contract. The underlying interests of a company do not give away negotiation strategies-it does not mean that a manager invites exploitation. Instead, managers should explain the broader interests of their company as a prelude to negotiating the contract. (Barton, Haapio \& Borisova 2015, pp. 19-20)

These ideas can be startling, and resisted, because they seem to contradict so much conventional wisdom about proper negotiating style and the power that is assumed to flow from possessing secret information. True, one should not normally disclose the "reservation point" below which one would terminate negotiations. But sharing one's interests and basic goals with a contracting counterpart is virtually a precondition to discovering "win-win" possibilities. All value in exchange flows from learning that another person values something more highly than we are able and willing to supply. Unless people communicate what they want, those needs and possible value-enhancing exchanges may never become visible. 
Further, unless the deeper interests are disclosed, parties may never consider unconventional ways - contract terms apart from price-by which both parties may emerge even more satisfied with the transaction. The mutual exchange of information is thus a precursor to immediate value-creation, but also to longer-term relationships. How does one convince a skeptical contracting counterpart of the wisdom of this approach? The unilateral disclosure of one's own underlying interests, coupled with an offer to listen to the interests of a contracting counterpart, is an important step toward realizing hidden value and better relationships.

In Part 4 below, we offer some examples in which the tools of business-friendly contracting have been effectively used.

\section{Business-Friendly Contracting: Examples and Implementation}

User-centered design, simplification, and visualization have already made their way to some practitioners' ways of working. In the field of consumer contracts, experiments have proven how loan documents and credit card agreements can benefit from a new, more user-friendly approach (US Consumer Financial Protection Bureau CFPB 2011; Siegel \& Etzkorn 2013). Further projects have aimed to simplify, for example, an online game's terms of service, a rail network's disclaimer, and a law firm's standard terms of engagement (Clarity2010 Blog; UK Office of Fair Trading OFT 2011). Several projects have looked into the simplification of online Terms \& Conditions, end-user licenses, and privacy policies through the use of icons (For a summary, see Lannerö 2013).

The proponents of plain language (Felsenfeld \& Siegel 1981; Kimble 2006, 2012), simplification (Waller 2011a, 2011b; Etzkorn 2011), minimalism (Hetrick 2008) and lean contracting (Weatherley 2005; Siedel \& Haapio 2010, 2011) have suggested major changes 
in document design and drafting, but until recently, not much seems to have happened in the specific field of contracting. Instead, the trend seems to have been toward more complex contracts. For example, in the 1980 s a typical credit card contract was perhaps a page and a half or two pages long - but now it may easily cover twenty to thirty pages.

\subsection{Case Studies of Business-Friendly Contracting and Simplified Contracts}

Even in the commercial contracting arena, however, some pioneering organizations and innovative professionals have experimented with simpler contracting processes and documents.

\subsubsection{Scottish and Newcastle - The Pathclearer Approach}

The Pathclearer approach developed by the in-house legal team at Scottish \& Newcastle plc (S\&N) offers a first example. The legal team at S\&N found that in many cases, detailed contract terms were unnecessary, and that too much detail could actually be an obstacle to doing business. S\&N developed an innovative approach which helped reduce paperwork and better identify legal risk (Colquhoun 2007; Weatherley 2005. See also Siedel \& Haapio 2011, pp. 119-121). They moved from conventional contracts - tens of pages and exhibits full of dense text - to brief texts, such as the Pathclearer Supply Agreement: a brief letter agreement that drastically reduced the length and complexity of the contract.

\subsubsection{Agilent Technologies - The 50/50/500 Plan}

Another example of contract simplification is offered by Dave Barton $(2008)^{16}$, Director of Contracts at Agilent Technologies. For Agilent Technologies' Customer Contracts organization, the goal of simplicity in agreements was not enough. In what they called a

\footnotetext{
${ }^{16}$ No relation to this Chapter's co-author of the same surname.
} 
"50/50/500 Plan", they set numerical goals: reduce the length of most common agreements by at least 50 percent; reduce negotiation cycle time by 50 percent; and provide more empowerment on contract terms for deals of $\$ 500,000$ or less. In one example, a services division had previously consolidated six different exhibits describing six different services into one long document of 17 pages. The comprehensive document was efficient in some ways for Agilent: they did not need to worry about which set of terms and conditions to use when preparing quotes and processing customer orders. However, less complexity for Agilent meant more complexity for customers: rarely did a customer require more than one of the services described in the contract. Agilent was routinely sending its customers a 17page document of which, at most, three pages might apply to their particular needs. The document did not fully take into account its multiple users, and as a result some users had to waste time determining which part of the document was pertinent to their particular transaction.

As part of their 50 percent simplification goal in the 50/50/500 Plan, Agilent broke the document apart and re-drafted it into six separate documents, none longer than three pages. The resulting contract was much less complex for the customer. At the same time, Agilent's contracts organization increased its capacity to focus on higher value-added business relationships and issues. According to Dave Barton (2008): “The plan restored a sense of purpose in alignment with corporate goals, and this has reinvigorated a great sense of pride."

\subsubsection{IBM Cloud Services}

IBM recently simplified their contract for cloud services offerings, reducing a contract that once was between 30 to 90 pages long, to a contract that is a mere two pages. 
This project was named a finalist for the 2014 IACCM Innovation Award for Operational Improvement. Based on the positive market feedback regarding the simplified Cloud Services Agreement (CSA), IBM has extended the simplified contracting approach and now has a short, simple, modular master contract based upon the CSA which applies to all of IBM's offerings, including Cloud, Machines, Appliances, Software and Services (IACCM 2014c). According to Neil Abrams, Assistant General Counsel at IBM, they learned that using a shorter contract takes much less time for the customers and their lawyers. Where there needs to be some negotiation, that can be done faster too (Reisinger 2014). When he began the task, Abrams was the head lawyer for software. Now he is an assistant GC assigned to look for ways to transform the client experience, including simplifying more contracts - all part of the legal team's focus on helping their business satisfy clients and innovate (Reisinger 2014). Webcast recordings illustrating the process and its outcomes are available at the IACCM website (IACCM 2014b, 2015c).

\subsubsection{The New Engineering Contract (NEC)}

A noteworthy example of using visuals to guide the use and interpretation of complex commercial contracts comes from the UK: the NEC family of contracts. This set of documents consists of several contracts designed for procuring a diverse range of services and goods, plus associated guidance notes and flow charts that assist in the understanding of those contracts. Originally launched in 1993 under the name of the "New Engineering Contract", NEC has been praised for its collaborative and integrated working approach to procurement. The implementation of NEC3 contracts reportedly has resulted in major benefits for projects both nationally and internationally in terms of time, cost savings and improved quality (See NEC 2014b, 2014c, 2014d). In their comparison between NEC and 
FIDIC conditions, the publishers of NEC praise their standard form of contract by noting: "It is probably fair to say that FIDIC focuses on liabilities and risk in the manner of traditional contracts, whereas NEC requires and enables a more proactive and collaborative approach" (NEC 2014a, p. 2). The NEC publishers also highlight that "a feature of NEC is the drafting in plain English and providing for clarity and flexibility. NEC attempts to eliminate the use of legal terms and instead provides for simple language, and gives words their natural meaning" (NEC 2014a, p. 2).

\subsubsection{Rolls Royce, plc.}

At the IACCM Academic Forum of 2013, Shad Haddad (Lead Commercial Officer of Rolls-Royce plc.) presented a paper that reflected on contract visualization in infrastructure development, from both pre- and post-contract award perspectives (Haddad 2013). He first asked about an organization's purpose in entering into a contract: is it to enforce in court or arbitration various obligations on the other party and gain compensation for their failure in undertaking them; or is it rather to provide a statement or formal commitment to the undertakings of the organization's own obligations? Without giving an answer, he then pondered whether the overly complicated "legalese" way of drawing up contracts provides for adequate clarity and accurate interpretation of the obligations of the parties, especially in an already complex project. He concluded that visualizations can help integrate law (especially Proactive Law) and contract management, and transform legal documents into enabling instruments. His paper included examples of how visualization techniques can provide the parties with clarity on what they require and what they should deliver, thereby helping to promote contractual compliance and shape the procurement process. 


\subsection{Research on Contract Simplification and Visualization}

In different parts of the world, pioneering scholars have started to experiment with user-centered contract design and contract visualization. Michael Curtotti and Eric McCreath of the Australian National University have developed prototype tools for visualizing contract definitions in different ways (Curtotti \& McCreath 2012). Stefania Passera, at Aalto University, has developed and prototyped visual contracts in collaboration with private and public organizations. ${ }^{17}$ Together with Michael Curtotti and one of this chapter's authors, she has experimented with a prototype of automated contract visualization (Passera, Haapio \& Curtotti 2014). At Stanford University, Margaret Hagan and George Triantis are working with students to tackle consumer-contract design challenges, studying, among other things, principles of contract design, communication design, and behavioral economics to understand the dynamics of how lay people interact with legal text and choices. ${ }^{18}$

Researchers who have viewed contracting as an ongoing, common sense-making process between the parties have found that visualization can play an important role in helping the contract parties avoid misunderstandings and inadvertent non-compliance (Passera, Haapio \& Curtotti 2014). Contract visualization has been presented as a way to implement a proactive approach to contracting and law, helping the parties not only to prevent disputes and litigation, but also to enhance the likelihood of successful business outcomes and a mutually beneficial relationship (Passera, Haapio \& Curtotti 2014). The usability and user-experience of the new contract prototypes are in the process of being

\footnotetext{
${ }^{17}$ For examples of the published results of this work, see the web pages of M!ND research group, http://www.mindspace.fi/en/contract-visu/ and Why contracts need visualization? http://www.mindspace.fi/en/english-why-contracts-need-visualization/.

${ }^{18}$ Legal Design Lab: Consumer Contracts, https://law.stanford.edu/courses/legal-design-lab-consumercontracts/.
} 
evaluated. Early case studies are preliminary but encouraging: they clearly indicate positive results and a strong user preference for a simplified and visualized contract as opposed to a traditional, text-only version (Passera 2012, 2014, 2015; Passera and Haapio 2013a, 2013b). The new approach obviously involves risks. As regards visualization, questions such as potential conflicts between text and images need to be resolved. Some of these questions can be resolved contractually, and others require further investigation. More prototypes, user tests and research are required to analyze, for example, which methods work best for which users or contexts. In any case, the early results indicate that the benefits outweigh the risks, and that much can be gained by merging contract design with information design and visualization.

\section{Conclusion}

Security and opportunity are not necessarily mutually exclusive. Even while the authors of this chapter welcome a shift toward a paradigm of opportunity, that new emphasis need not come at the expense of a secure foundation of contractual agreement. Our chapter has demonstrated how employing the principles and methods of PPLespecially simplification, visualization, and collaboration--can enhance security and opportunity simultaneously.

Advancing security and opportunity together in contracting is possible because PPL methods can transcend what causes security and opportunity to appear as inherently opposed: the traditional divergence in outlook, goals, and language between law and business. Framing contract goals as prevailing in court or limiting legal damages will emphasize standardized, litigation-tested disclaimers and indemnification clauses-exactly those terms that IACCM finds to be high on the agendas of many legally-focused contracts 
negotiators. A moment's reflection, however, reveals how stifling of opportunities those clauses are likely to be. They suggest on their face a mentality of self-protection through rigidity, and veiled threats to bring the power of the law against a contract partner-hardly an environment that encourages innovation.

In contrast is the business mentality that seeks stronger (and typically longerenduring) economic and personal relationships with another party. A relational focus will expect occasional disruptions in contractual implementation. This focus will also accept the need to be flexible and accommodating, based on a reservoir of trust and long-term mutual benefit.

Although a relational mentality may be uppermost in the minds of those who negotiate the real deal, it is not often expressed in the paper deal. When economic and relational intentions are formalized into legal contracts, everyday language is translated and communications norms are transformed. The agreements suddenly become inaccessible to non-experts - those who must implement the agreement as well as those who may have negotiated the deal. Furthermore, communication expectations may be disrupted, or rendered self-protective or suspicious - all in the name of ensuring legally "the security of contracts." Little wonder, then, that security and opportunity appear opposed to one another. Where business and legal language and communication styles are so strongly compartmentalized, security and opportunity are never part of a shared agenda.

In every realm of law, PPL methods seek a healthy integration of stronger personal engagement, attention to factual environments, and legal possibilities. PPL aims not only to prevent legal disputes by better long-range planning and design, but also to enable parties to reach individual goals, mutual benefits, and new opportunities. PPL examines the systemic, patterned interactions of people to uncover and explain recurring points of 
friction or lost value. It then suggests interventions by which the revealed dissonance is resolved-and often transcended toward greater possibilities.

So also in our examination of contracting: diagnosis of traditional patterns reveals lost value through failure of adequate communication, which in turn is caused by an exaggerated and unnecessary separation of business and legal professionals. The "treatment" suggested in this chapter is simplification and visualization of contracting language, plus the creation of collaborative structures and practices. If implemented, these PPL interventions may enhance security of agreements through greater understanding, flexibility and trust. Simultaneously, they can facilitate collaborative refinements and new business opportunities for each contracting partner.

\section{References}

Barton D (2008) Using measurements to drive organizational value. Contracting Excellence, November 2008. International Association for Contract and Commercial Management IACCM. http://www2.iaccm.com/resources/?id=8030. Accessed 30 March 2016

Barton TD (2007) Three modes of legal problem solving-and what to do about them in legal education. California Western Law Review 43:389-416.

http://works.bepress.com/thomas_barton/10/. Accessed 30 March 2016

Barton TD (2008) A paradigm shift in legal thinking. Six contrasts of traditional and preventive/proactive legal thought. In: Haapio $\mathrm{H}$ (ed) A proactive approach to contracting and law. International Association for Contract and Commercial Management \& Turku University of Applied Sciences, Turku, pp. 35-42.

Barton TD (2009) Preventive law and problem-solving: Lawyering for the future. Vandeplas Publishing, Florida.

Barton TD (2012) Collaborative contracting as preventive/proactive law. In: Berger-Walliser G, Østergaard K (eds) Proactive law in a business environment. DJOF Publishing, Copenhagen, pp. 107-127.

Barton TD (2016, forthcoming) Re-designing law and lawyering for the information age. Notre Dame Journal of Law, Ethics \& Public Policy 30:101-134.

Barton TD, Berger-Walliser G, Haapio H (2013) Visualization: Seeing contracts for what they are, and what they could become. Journal of Law, Business \& Ethics 9:47-63. 
Barton TD, Haapio H, Borisova T (2015) Flexibility and stability in contracts. Lapland Law Review, Issue 2, pp. 8-28. http://www.ulapland.fi/InEnglish/Units/Faculty-of-

Law/Research/Lapland-Law-Review/Issues/Issue-2,-2015. Accessed 30 March 2016

Berger-Walliser $\mathrm{G}$ (2012) The past and future of proactive law: An overview of the development of the proactive law movement. In: Berger-Walliser G, $\varnothing$ stergaard K (eds) Proactive law in a business environment. DJOF Publishing, Copenhagen, pp. 13-31.

Berger-Walliser G, Barton T, Haapio $\mathrm{H}$ (forthcoming) From visualization to legal design.

Berger-Walliser G, $\varnothing$ stergaard K (eds) (2012) Proactive law in a business environment. DJOF Publishing, Copenhagen.

Bergman J (2015) 2015 top terms in negotiating - review \& analysis - AMERICAS 2015. https://www.iaccm.com/resources/?id=8856 (for members only). Accessed 30 March 2016

Brown LM (1956) The law office. A preventive law laboratory. University of Pennsylvania Law Review 104(7):940-953.

Clarity2010 Blog. http://blog.clarity2010.com. Accessed 30 March 2016

Colquhoun G (2007) A clearer way to deal. The Journal, January 2007, p. 45.

Creative Commons (2015) About the licenses. http://creativecommons.org/licenses.

Accessed 30 March 2016

Cummins T (2015) Commercial excellence. Presentation at IACCM Finland event, Helsinki 14 September 2015.

Cummins T, Crawford J (2010) Collaborative contracting: Is it achievable? Webinar conducted under the auspices of IACCM, 8 April 2010.

http://www2.iaccm.com/resources/?id=3446 (for members only). Accessed 30 March 2016

Curtotti M, McCreath E (2012) Enhancing the visualization of law. Paper presented at the 2012 Law via the Internet Twentieth Anniversary Conference, Cornell University, 9 October 2012. http://ssrn.com/abstract=2160614. Accessed 30 March 2016

Dauer EA (1988) Corporate legal health: Preventive law dictates going to root causes to prevent claims from arising. Preventive Law Reporter, September, p. 12.

DiMatteo L, Siedel G, Haapio H (2012) Strategic contracting: Examining the business-legal interface. In: Berger-Walliser G, Østergaard K (eds) Proactive Law in a Business Environment. DJ $\varnothing$ F Publishing, Copenhagen, pp. 59-106.

EESC (2009) Opinion of the European Economic and Social Committee on 'The pro-active law approach: a further step towards better regulation at EU level'. Official Journal of the European Union, 2009/C175/05, pp. 26-33. http://eur-lex.europa.eu/legalcontent/EN/TXT/PDF/?uri=CELEX:52008IE1905\&from=EN. Accessed 30 March 2016

Ertel D (2004) Getting past yes: Negotiating as if implementation mattered. Harvard Business Review 82(11):60-68.

Etzkorn IA (2011) Ten commandments of simplification. Center for Plain Language. August 2011. http://bustthefacts.blogspot.fi/2011/08/ten-commandments-of-simplification.html. Accessed 30 March 2016

Felsenfeld C, Siegel A (1981) Writing contracts in plain English. West Publishing Co. 
Haapio H (1998) Quality improvement through proactive contracting: Contracts are too important to be left to lawyers! In: Proceedings of Annual Quality Congress (AQC), American Society for Quality (ASQ), Philadelphia, PA, Vol. 52, May 1998, pp. 243-248.

Haapio H (2006) Introduction to proactive law. In: Wahlgren P (ed) A Proactive Approach. Scandinavian Studies in Law, Vol. 49. Stockholm Institute for Scandinavian Law, Stockholm, pp. 21-34. http://www.scandinavianlaw.se/pdf/49-2.pdf. Accessed 30 March 2016

Haapio H (ed) (2008) A proactive approach to contracting and law. International Association for Contract and Commercial Management \& Turku University of Applied Sciences, Turku.

Haapio H (2013a) Good contracts: Bringing Design thinking into contract design. In: Chittenden J (ed) Proceedings of the 2013 IACCM Academic Forum. International Association for Contract and Commercial Management, Ridgefield (CT), pp. 95-136. http://www.iaccm.com/resources/?id=4958 (for members only). Accessed 30 March 2016 Haapio H (2013b) Next generation contracts: A paradigm shift. Lexpert Ltd, Helsinki. Haapio H, Passera S (2013) Visual law: What lawyers need to learn from information designers. VoxPopuLII Blog, 15 May 2013. Legal Information Institute, Cornell University Law School. http://blog.law.cornell.edu/voxpop/2013/05/15/visual-law-what-lawyers-need-tolearn-from-information-designers/. Accessed 30 March 2016

Haddad S (2013) Integration of law and contract management - Applying Contract visualization. In: Chittenden J (ed) Proceedings of the 2013 IACCM Academic Forum. International Association for Contract and Commercial Management, Ridgefield (CT), pp. 52-73. http://www.iaccm.com/resources/?id=4958 (for members only). Accessed 30 March 2016

Hetrick PK (2008) Drafting common interest community documents: Minimalism in an era of micromanagement. Campbell Law Review 30(3):409-435.

http://scholarship.law.campbell.edu/cgi/viewcontent.cgi?article=1472\&context=clr. Accessed 30 March 2016

Hughes S (2015) Commercial excellence: Ten pitfalls to avoid in contracting. IACCM Ask The Expert, 6 March 2015. International Association for Contract and Commercial Management IACCM. https://www.iaccm.com/resources/?id=8451 (for members only). Accessed 30 March 2016

IACCM (2014a) 2013/2014 top terms. International Association for Contract and Commercial Management IACCM. 23 May 2014. https://www.iaccm.com/resources/?id=7619. Accessed 30 March 2016

IACCM (2014b) The IACCM innovation awards: Celebrating excellence \& innovation in contracting. International Association for Contract and Commercial Management IACCM. 19 September 2014. https://www.iaccm.com/resources/?id=7840. Accessed 30 March 2016

IACCM (2014c) IBM - Finalist - Operational improvement award. News 6 December 2014, International Association for Contract and Commercial Management IACCM. https://www2.iaccm.com/resources/?id=8288. Accessed 30 March 2016

IACCM (2015a) Commercial excellence: Ten pitfalls to avoid in contracting. [Booklet] International Association for Contract and Commercial Management, Ridgefield (CT). 
IACCM (2015b) Top negotiated terms 2015: No news is bad news. International Association for Contract and Commercial Management IACCM.

http://www2.iaccm.com/resources/?id=8930 (for members only). Accessed 30 March 2016

IACCM (2015c) Webinar - Innovative contract management: How to infuse simplification into your contracts. 1 December 2015, International Association for Contract and Commercial Management IACCM. https://www2.iaccm.com/resources/?id=8997 (for members only). Accessed 30 March 2016

Jennejohn M (2008) Collaboration, innovation, and contract design. Stanford Journal of Law, Business \& Finance 14(1):83-150.

Kimble J (2006) Lifting the fog of legalese. Carolina Academic Press, Durham (NC).

Kimble J (2012) Writing for dollars, writing to please. The case for plain language in business, government, and law. Carolina Academic Press, Durham (NC).

Lannerö P (2013) Fighting the biggest lie on the Internet: Common terms beta proposal. 30 April. Metamatrix, Stockholm.

http://www.commonterms.net/commonterms_beta_proposal.pdf. Accessed 30 March 2016

Macaulay S (2003) The real and the paper deal: empirical pictures of relationships, complexity, and the urge for transparent simple rules. The Modern Law Review 66(1):44-79. doi:10.1111/1468-2230.6601003.

http://www.law.wisc.edu/facstaff/macaulay/papers/real_paper.pdf. Accessed 30 March 2016

Malhotra D (2012) Great deal, terrible contract: The case for negotiator involvement in the contracting phase. In: Goldman BM, Shapiro DL (eds) The psychology of negotiations in the 21st century workplace. New challenges and new solutions. Routledge, New York (NY), pp. 363-398.

Mosten FS (2009) Collaborative divorce handbook: Helping families without going to court. Jossey-Bass, San Francisco.

NEC (2014a) A Comparison of NEC and FIDIC.

https://www.neccontract.com/getmedia/2bd4ffb9-8e1e-4684-af86-1d913152f10d/A-

comparison-of-NEC-and-FIDIC-by-Rob-Gerrard.pdf.aspx. Accessed 30 March 2016

NEC (2014b) About NEC. https://www.neccontract.com/About-NEC. Accessed 30 March 2016

NEC (2014c) Products. https://www.neccontract.com/Products. Accessed 30 March 2016

NEC (2014d) Why NEC3? https://www.neccontract.com/About-NEC/Why-NEC. Accessed 30 March 2016

Nystén-Haarala S (ed) (2008) Corporate contracting capabilities. Conference proceeding and other writings. University of Joensuu Publications in Law, No 21. University of Joensuu, Joensuu.

Passera S (2012) Enhancing contract usability and user experience through visualization - an experimental evaluation. In: Banissi E et al (eds) 16th International Conference on 
Information Visualisation, IV2012, 11-13 July 2012, Montpellier, France. IEEE Computer Society, Los Alamitos (CA), pp. 376-382.

Passera S (2014) Contract understanding and usability test. Aalto University School of Science \& International Association for Contract \& Commercial Management.

https://www2.iaccm.com/resources/?id=7877 (for members only). Accessed 30 March 2016

Passera S (2015) Make your contracts visual and user-centered. In: FIMECC UXUS final report 1/2015 - User Experience and Usability in Complex Systems - UXUS. FIMECC Publications Series No. 8, pp. 181-186. http://hightech.fimecc.com/results/final-reportuxus-user-experience-and-usability-in-complex-systems. Accessed 30 March 2016

Passera S, Haapio H (2013a) Transforming contracts from legal rules to user-centered communication tools: a human-information interaction challenge. Communication Design Quarterly 1(3), pp. 38-45. http://sigdoc.acm.org/wp-content/uploads/2012/09/CDQ-April1-3-FINAL.pdf. Accessed 30 March 2016

Passera S, Haapio H (2013b) The quest for clarity - how visualisation improves the usability and user experience of contracts. In: Huang ML, Huang W (eds) Innovative approaches of data visualisation and visual analytics. Advances in data mining and database management (ADMDM) series. IGI Global, Hershey (PA), pp. 191-217.

Passera S, Haapio H, Barton TD (2013) Innovating contract practices: Merging contract design with information design. In: Chittenden J (ed) Proceedings of the 2013 IACCM Academic Forum. International Association for Contract and Commercial Management, Ridgefield (CT), pp. 29-51. http://www.iaccm.com/resources/?id=4958 (for members only). Accessed 30 March 2016

Passera S, Haapio H, Curtotti M (2014) Making the meaning of contracts visible Automating contract visualization. In: Schweighofer E, Kummer F, Hötzendorfer W (eds) Transparenz. Tagungsband des 17. Internationalen Rechtsinformatik Symposions IRIS 2014 / Transparency. Proceedings of the 17th International Legal Informatics Symposium IRIS 2014. Österreichische Computer Gesellschaft OCG, Wien, pp. 443-450.

Patajoki U (2013) Towards a successful contractual relationship. Public service procurement from a small business perspective. Master's Thesis, 27 August 2013, Aalto University, School of Science, Degree Programme in Information Networks. http://tuta.aalto.fi/en/midcomserveattachmentguid1e47559bc2ceb62755911e4a2f4dd39aba9b4fdb4fd/ulla_patajoki_masters_thesis_final.pdf. Accessed 30 March 2016

Pohjonen S (2002) Johdanto [Introduction]. In: Pohjonen S (ed) Ennakoiva sopiminen liiketoimien suunnittelu, toteuttaminen ja riskien hallinta [Proactive contracting - planning, implementing and managing risk in business transactions]. WSOY Lakitieto, Helsinki, pp vxiii.

ProActive ThinkTank mission statement (2007)

http://www.juridicum.su.se/proactivelaw/main/thinktank/missionstatement.pdf. Accessed 30 March 2016

Reisinger S (2014) How IBM shrunk a complex contract down to 2 pages. 16 December 2014. https://www2.iaccm.com/resources/?id=8527 (for members only). Accessed 30 March 2016 
Siedel GJ, Haapio H (2010) Using proactive law for competitive advantage. American Business Law Journal 47(4):641-686. doi:10.1111/j.1744-1714.2010.01106.x.

Siedel G, Haapio H (2011) Proactive law for managers: A hidden source of competitive advantage. Gower, Farnham.

Siegel A, Etzkorn I (2013) Simple - Conquering the crisis of complexity. Twelve, New York \& Boston.

Szabo N (2010) Design thinking in legal practice management. Design Management Review 21(3):44-46. doi: 10.1111/j.1948-7169.2010.00078.x

UK Office of Fair Trading (OFT) (2011) Consumer contracts - What you need to know. OFT1318, March 2011.

http://webarchive.nationalarchives.gov.uk/20140402142426/http://www.oft.gov.uk/shared _oft/market-studies/consumercontracts/OFT1318_Consumer_Contracts_1.pdf. Accessed 30 March 2016

US Consumer Financial Protection Bureau (CFPB) (2011) CFPB aims to simplify credit card agreements. Agency announces plans to pilot test prototype agreement; Invites public to weigh in. 7 December 2011. http://www.consumerfinance.gov/pressrelease/consumerfinancial-protection-bureau-aims-to-simplify-credit-card-agreements. Accessed 30 March 2016

Wahlgren P (ed) (2006) A proactive approach. Scandinavian studies in law, Vol. 49. Stockholm Institute for Scandinavian Law, Stockholm.

Waller R (2011a) Information design: how the disciplines work together. Technical paper 14. Simplification Centre.

http://www.simplificationcentre.org.uk/downloads/papers/SC14DisciplinesTogether.pdf. Accessed 30 March 2016

Waller R (2011b) What makes a good document? The criteria we use. Technical paper 2. Simplification Centre.

http://www.simplificationcentre.org.uk/downloads/papers/SC2CriteriaGoodDoc_v2.pdf. Accessed 30 March 2016

Waller R (2011c) Simplification: what is gained and what is lost. Technical paper 1. Simplification Centre.

http://www.simplificationcentre.org.uk/downloads/papers/SC1SimplificationGainedLostv2.pdf. Accessed 30 March 2016

Waller R (2015) Layout for legislation. Technical paper 15. Simplification Centre. http://www.simplificationcentre.org.uk/downloads/papers/SC15LayoutLegislation-v2.pdf. Accessed 30 March 2016

Weatherley S (2005) Pathclearer: A more commercial approach to drafting commercial contracts. PLC Law Department Quarterly, October-December, pp. 39-46.

http://www.clarity-international.net/documents/Pathclearer\%20article\%20in\%20PLC-3.pdf. Accessed 30 March 2016 